\title{
Collective Bargaining and Faculty Status: A Twenty-Year Case Study of Wayne State University Librarians Lothar Spang
}

Faculty status for librarians has been an increasingly problematic issue in collective bargaining at Wayne State University (WSU) for over twenty years. From the 1970s through the early 1980s, WSU librarians achieved near parity with faculty in compensation, job security, and governance matters. However, incursions on these gains began in 1984, and by 1992 librarians at the university were losing certain salary accomplishments, tenure options, and sabbatical and promotion rights. Documentation of the evolution of these successes and failures reveals the challenges for academic librarians in seeking faculty status through collective bargaining.

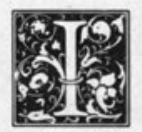

n 1972, Wayne State University (WSU), located in Detroit, Michigan, became one of the first research universities in the United States to institute collective bargaining for its faculty and professional staff, including librarians. Over the years, the number of WSU librarians in the American Association of University Professors (AAUP), the bargaining agent, has consistently remained above 70 percent, even though WSU's faculty membership has rarely reached 60 percent. Only a few librarians, mostly for philosophical reasons, are not union members.

In twenty years, nine contracts between representatives of the WSU-AAUP and the university administration have been signed, and collective bargaining has endured as the major means of librarian and faculty resolution of compensation, job security, and governance questions. Despite initial gains, however, faculty status for librarians has become a progressively contentious issue during the bargaining process, especially as economic conditions have worsened.

From 1972 to 1976 , contracts established a framework in which WSU librarians realized sizeable gains in tenure, compensation, and participatory management. These gains helped them approach but not reach faculty status. From 1976 to 1984 , the contract details of these issues were refined so that librarians reached near parity with faculty. But by 1984 these gains began to erode, resulting by 1992 in librarians' losing salary gains, tenure options, certain sabbatical privileges, and some promotion rights. Tracing the successes and failures of WSU librarians in their quest for faculty status reveals the profound challenges of seeking such status through collective bargaining.

\section{TOWARD UNIONIZATION}

In 1968, WSU administrators formulated a universitywidestaffing reorganization plan that separated faculty from other professional staff in matters regarding

Lothar Spang is Reference Librarian at Shiffman Medical Library, Wayne State University, Detroit, Michigan 48202. 
compensation and tenure. Tenure was to be restricted to teaching faculty only, and a separate salary schedule was to be instituted for each employee grouping. Previously, tenure had been available to all professional staff, such as librarians. Rather than tenure, the new plan, for job security purposes, offered these groups a continuing service contract based on seniority. The plan was similar to that offered to civil service employees, meaning that a successful apprenticeship ensured a lifetime position. As for salaries, base nine-month faculty salary equated to base eleven-month librarian salary. And, although minimum salaries for librarians exceeded minimum faculty salaries, the average salaries of faculty as a group by 1968 had already far exceeded those of librarians as a group.

Librarians viewed the university's reorganization plan as an immediate threat to their job security and financial status. Ever mindful of professional status, librarians tried for three years to find what would be considered professional means of countering the plan. The library director, although supportive of the librarians' position, ultimately declined to assume a leadership role in solving their dilemma. Librarians contacted officials of the American Library Association (ALA) for advice, but the response was that ALA had not yet formulated a policy on such issues, particularly on collective bargaining.

Then, during Christmas vacation of 1971 , seventy-one nontenured faculty and eleven nontenured librarians (four of whom had multiple-year contracts) received notices of contract nonrenewal. No warning had been given. Influential senior faculty saw this move as a threat to the faculty role in university governance and prompted an immediate search for a bargaining agent. Librarians concurred.' A runoff election was held wherein voters were allowed to choose between the AAUP, the Detroit Federation of Teachers (the local chapter of the American Federation of Teachers), and no union. The AAUP prevailed, even though at the time the AAUP was more attuned to university teaching issues than to bargaining.
Because the AAUP could provide little constructive support in actual deliberations, the WSU-AAUP leadership decided to seek the help of advisors from the United Auto Workers (UAW). A librarian was selected as a member of the five-person WSU-AAUP faculty bargaining team. And the Librarians Assembly, formed by WSU librarians in 1970 as a collegial forum to deal with governance, prepared to serve as the official library body responsible for negotiation recommendations and contract implementation as it applied to librarians. The setup allowed the fifty-six librarians in the bargaining unit to be well positioned in the beginning to take advantage of the bargaining process. Parity with faculty in compensation, tenure, and governance was an immediate objective.

\section{THE FIRST TWO CONTRACTS: ESTABLISHING THE FRAMEWORK}

The 1972-74 contract made a modest start for librarians. Because the UAW advisor counseled against librarian and faculty desire to participate in governance, the salary and benefits issues were the main contract focus. As a group, librarians made a small gain in approaching overall faculty salaries, mainly because of an increased minimum in the salary schedule for librarians. More crucially, the contract addressed the function of the University Council and the role it played in the education process. Guaranteed to librarians was an equal role with faculty, which was a significant first step in librarian efforts to achieve equality in governance matters. The tenure issue was addressed after talks on this topic that, by mutual agreement of faculty and administration negotiators, lasted 120 days after the initial contract was signed. Librarians regained unit tenure rights, and even those new hires who had been given continuing service contracts were converted to the tenure track. But the faculty-status-for-librarians issue as it related to tenure and promotions remained largely undefined because librarians, at the time, could not resolve 
among themselves the issues of workload and release time. This was a portent of problems to come.

One compensation component had major implications for librarians. A unit selective salary clause mandated that librarians, like faculty, select their own review committee for merit decisions. By using written reviews supplied by supervisors, the initial review committee of seven librarians, selected by vote in the Librarians Assembly, recognized 46 percent of their colleagues for merit awards. This percentage matched exactly the decisions of library administrators the previous year and was accepted unconditionally by librarians. By contrast, faculty in some departments divided their merit awards either across the board or gave very small amounts, leaving some faculty who received as little as ten dollars unhappy. This action would affect the merit award process produced in the next contract.

\section{Because the UAW advisor counseled against librarian and faculty desire to participate in governance, the salary and benefits issues were the main contract focus.}

A President's Equity component of the 1972-74 contract provided monies for the university president to rectify "unfair" decisions of departmental salary committees. The administration soon began to use this extra discretionary fund to develop the "favored department" concept. This concept allowed larger sums of money to be available for merit in selected departments, creating special departmental loyalties to the administration. But librarians realized little extra merit consideration because the new library director, the librarians' main liaison with the central administration, had not yet developed influence with the university administration.

The 1972-74 contract also required that deans and directors consult salary committees about salaries offered to new staff, including librarians. In later con- tracts, this provision was not accepted voluntarily by administrators. Health and other related leaves of absence were also codified. For librarians, unlike faculty, this provision meant that vacation days, short-term leaves, and sick leave days were spelled out exactly. Sabbaticals were treated as a separate issue, but importantly the idea that librarians, like faculty, were eligible for sabbaticals was accepted.

The next contract, for 1974-76, added refinements that were pivotal for librarians. The economic settlement helped them as a group to approach, but not equal, overall faculty salary levels. Also, this contract established departmental procedures, similar to those followed by faculty, for librarians' tenure review and defined their committee memberships and review criteria. The Librarians Assembly, in conjunction with the library director, was to establish tenure criteria.

In addition to across-the-board raises, and as a means of rectifying previous inequities, each librarian received \$200. The Women's Equity Review Fund allowed several female librarians to receive salary equity settlements of as much as $\$ 2,000$. The equity adjustments were based on comparable-service male librarian salaries. Additionally, the contract stipulated that all promotions in rank would be recognized by $\$ 500$. Also established was an Early Retirement Review Committee to define guidelines and costs for early retirements for both faculty and academic staff.

In response to the dissension over the merit award process generated by the last contract, the AAUP bargainers, by compromise, got the university to agree to a centralized committee that would award 50 faculty $\$ 1,000$ and another 172 faculty $\$ 500$ each in place of departmental salary adjustment. This judgment error had to be corrected in the next contract. It was soon discovered that departments that had representatives on this committee received more awards than did faculty from departments that had no such representation. Librarians, each having received $\$ 200$ in this contract, were not eligible for this process. But, 
henceforth, from 1976, all collegial selective salary increases, including those for librarians, would be decided at the departmental or unit level.

In 1974 , the university agreed to withdraw from implementation a recent study done by the Hay Group of Chicago, a move that proved to be crucial for librarians. This consulting group, hired by the university to study all nonfaculty professional classifications and clerical positions, had separated teaching faculty from professional staff for the delineation of job assignments, productivity standards, and compensation. The plan was reminiscent of the university's 1968 staffing plan that had inspired unionization. This study was tabled when all unions insisted that any classification changes should be part of the bargaining process. But, again, the administration had shown that it was unwilling to consider librarians as faculty unequivocally.

As a result of the first two contracts, librarians were still separate from faculty in compensation and tenure considerations. But progress had been made, particularly in governance matters. Especially ominous for future job security, however, was the fact that librarian tenure remained in the library, whereas faculty tenure was universitywide.

\section{THE FOUR CONTRACTS FROM 1976 THROUGH 1986: ADDRESSING THE DETAILS}

\section{6-78}

Like the two previous contracts, the 1976-78 salary document was intended to help the lower paid classifications, such as librarians as a group, by designating the largest percentage of monies to these lower paid groups. The 1976-78 agreement increased entry level salaries and called for a $\$ 500$ promotional adjustment and merit award, as well as cost-ofliving adjustments; although these provisions were aimed especially at librarians, salaries of librarians and liberal arts faculty still showed a continually widening gap as shown in table 1.

The settlement also established a professional development component that provided special travel funds for academic staff to encourage research and participation in regional and national conferences. Also mandated was the establishment and publication of unit bylaws. Refinement of the shared governance process was continued by the establishment of a budget advisory committee for each unit, including the libraries, that would be closely involved in the university's budget process.

As a result of the first two contracts, librarians were still separate from faculty in compensation and tenure considerations. But progress had been made, particularly in governance matters.

By 1976, administrators, faculty, librarians, and union representatives began to realize the large amounts of time and commitment that participatory management, as mandated under contract, required. Some librarians also began to think that the review guidelines for promotion and tenure, based on faculty standards, did not recognize their performance. This complaint was particularly voiced by technical services librarians. They were librarians who thought they did their job well but, when preparing a curriculum vitae, had little visible evidence that would be recognizable by librarian colleagues and faculty on the second-level review committee that was advisory to the university president.

Many librarians opted not to seek election to committees or to participate in the governance process because of the commitment that each required. The frustration of governance showed in a report of the 1977-78 Libraries Tenure and Promotion Committee, which asked for guidance from the Librarians Assembly:

Now that librarians have had several years [sic] experience in the difficult task of judging their peers, we feel that some guidance from the Librarians Assembly on these matters would help the ... committee to function more consistently and would clarify 
TABLE 1

LIBRARIAN AND LIBERAL ARTS FACULTY SALARY COMPARISONS

BY CONTRACT AND IN PRACTICE FOR FOUR CONTRACTS

\begin{tabular}{|c|c|c|c|c|c|c|c|}
\hline \multirow[b]{2}{*}{ Contract } & \multirow[b]{2}{*}{ Rank } & \multicolumn{2}{|c|}{$\begin{array}{l}\text { Minimum Per Rank } \\
\text { as Stipulated by Contract }\end{array}$} & \multicolumn{4}{|c|}{ Average Salary in Practice } \\
\hline & & $\begin{array}{l}\text { Librarians } \\
11 \text { Months }\end{array}$ & $\begin{array}{l}\text { Faculty } \\
9 \text { Months }\end{array}$ & $\begin{array}{l}\text { Librarians } \\
11 \text { Months }\end{array}$ & $\begin{array}{l}\text { Faculty } \\
9 \text { Months }\end{array}$ & $\begin{array}{r}\text { Dollar } \\
\text { for L } \\
\end{array}$ & $\begin{array}{l}\text { Difference } \\
\text { Librarians }\end{array}$ \\
\hline \multirow[t]{4}{*}{$1974-76$} & I & \$ 9,849 & $\$ 8,950$ & $\$ 10,303$ & \$ 9,704 & $\$$ & +599 \\
\hline & II & 11,980 & 10,450 & 12,705 & 13,014 & & -209 \\
\hline & III & 13,823 & 13,300 & 15,284 & 17,000 & & $-1,776$ \\
\hline & IV & 16,242 & 16,200 & 18,355 & 21,986 & & $-3,631$ \\
\hline \multirow[t]{4}{*}{$1980-82$} & I & 12,840 & 12,000 & 14,121 & 14,487 & & -366 \\
\hline & II & 16,610 & 14,000 & 18,050 & 18,116 & & -066 \\
\hline & III & 18,030 & 17,500 & 21,520 & 23,848 & & $-2,326$ \\
\hline & IV & 21,180 & 21,500 & 27,836 & 31,497 & & $-2,661$ \\
\hline \multirow[t]{4}{*}{$1984-86$} & I & 14,580 & 13,950 & 16,791 & 17,756 & & -965 \\
\hline & II & 17,730 & 16,250 & 22,588 & 22,991 & & -403 \\
\hline & III & 20,480 & 20,250 & 27,192 & 28,646 & & $-1,454$ \\
\hline & IV & 24,050 & 25,000 & 33,875 & 39,076 & & $-5,201$ \\
\hline \multirow[t]{4}{*}{$1988-90$} & I & 18,000 & 18,000 & 24,022 & 26,526 & & $-2,540$ \\
\hline & II & 20,000 & 20,000 & 28,989 & 31,658 & & $-2,669$ \\
\hline & III & 23,032 & 22,415 & 32,531 & 36,546 & & $-4,015$ \\
\hline & IV & 27,055 & 27,588 & 38,137 & 48,800 & & $-10,663$ \\
\hline
\end{tabular}

Note: Figures compiled from Wayne State University-American Association of University Professors salary tabulations for respective years. Cited with the permission of the WSU-AAUP. 
some of their responsibilities as well as librarian expectations. ${ }^{2}$

Early in the process, librarians had decided to use supervisory evaluations as the only written tool for collegial review for salary, promotion, and tenure matters. This procedure differed from the faculty's procedure in which collegial evaluation was definitive. It was not clear in 1976-78 who should communicate committee decisions to librarians or if previous committee minutes and notes in the personnel file could be used in evaluations. In response, the Librarians Assembly voted to remove previous committee decisions from the files, and to continue using supervisor evaluations but not to rank them as requested by the administration. The Librarians Assembly also voted to ask that administrators communicate to librarians both administration and committee decisions in order to allow librarians to appeal decisions to the appropriate body.

Librarians, however, were unable to reach agreement among themselves on the weighting of the research, publication, and service component of the review process, as mandated by the contract provisions. For faculty, teaching quality was given little consideration in such review. But librarians could not dismiss everyday job performance in the same manner. Nor could they fit job performance under "research." This dilemma would result in the rewriting of such criteria in each contract after 1976. The continuing uncertainty created by these rewrites would have far-reaching implications for all future negotiations and contract implementation.

\section{9-81}

Settlement of the 1979-81 contract was not achievable until a united strike was called by a coalition of the WSU-AAUP, the clerical union, and the paraprofessional union. The AAUP settled first, leaving the two other unions out and creating antagonisms that persist to the present. This lack of a united front among unions would have implications for future negotiations with an increasingly hard-line administration.
For librarians as a group, the economic gains were especially significant in the 1979-81 contract. The compensation package called for a modest 3.7 percent across-the-board increase, but provided for a classification adjustment that, for the first time, linked librarian and faculty titles. Additionally, all academic staff received a 2 percent equity adjustment to bring average salaries more in line with those of the teaching faculty. A unique aspect of the settlement for faculty and librarians was the 1.4 percent salary adjustment based on enrollment figures and student credit hours for the fall term of 1980 .

This contract was the first in which the local AAUP chapter representatives indicated a willingness to pursue the issue of faculty titles for librarians. During negotiations, the president of the AAUP chapter wrote the following to the Librarians Assembly:

I understand that "titles" may not in themselves mean much to certain individuals but in my mind faculty rank would more clearly acknowledge the professionalism of WSU librarians. ${ }^{3}$

This affirmation proved to be the closest that librarians would come in twenty years to achieving faculty titles and was one of the last issues given up at the bargaining table in the 1979-81 contract talks. The negotiating team surmised that the faculty would not strike for this issue and neither would many librarians. This perception continues more than a decade later.

\section{1-83}

The next contract, 1981-83, followed the compensation pattern of earlier contracts: the across-the-board portion was the largest part of the package. But because concerted union negotiator efforts improved entry-level pay scales, librarians benefited more than faculty. Unique to the contract was a clause that recognized longevity by providing a 1 percent increase for staff with fifteen years of service. Although the depressed economy in Michigan made the overall compensation package slightly lower than in previous years, the contract did establish a dental 
plan. The President/Dean's Selective Salary Adjustment Fund was at .25 percent, but in subsequent contracts this portion of the package would grow dramatically, with ever-widening implications for librarians.

By 1981, librarians began to use contract language to their extreme benefit, particularly the budget advisory committee clause which enabled them to meet with the provost to detail reasons why the libraries should not be part of the universitywide budget reduction of 2 percent. Although this effort was only partially successful, in that some small budget cuts were still made, librarians had now realized a new empowerment.

As in previous.contracts, however, the Librarians Assembly kept librarians focused on issues relating primarily to salary and job security. Faculty status, as it related to the ability to choose appropriate areas for study and research and the necessary release time to accomplish these goals, was still an uneasy topic.

\section{4-86}

The 1979-81 and 1981-83 contracts represented the high point of bargaining for librarians. The 1984-86 settlement began the downward spiral that would culminate in the late 1980 s with the loss of viable tenure and promotion rights and many compensation accomplishments. The salary disparity between the upper ranks of librarians and faculty continued to increase (see table 1). And by the 1984 negotiations, librarians had become so mired in the issues of criteria for faculty status that they failed to adequately represent their bargaining position to the AAUP negotiating team. The team was comprised of teaching faculty and academic staff who were unable to articulate librarian needs in the negotiating process. The Librarians Assembly proved to be ineffectual, even in an advisory role. Also, a new dean of libraries had been appointed and had not yet demonstrated a position on the issue of faculty status for librarians. Without the active support of union negotiators or library administrators, librarians were especially vulnerable to encroachments on their status.
Also, the contract talks became openly adversarial in 1984 over the issue of merit pay versus across-the-board pay, as well as the related issues of tenure, promotions; faculty rights and privileges. The WSU-AAUP was unable to present a strong counterfront to administration demands. And from this date forward, an intractable management stance that was invoked at each turn of bargaining talks and contract implementation was to have marked consequence for librarians.

In the 1984-86 contract, a detailed layoff and recall procedure in which the university could declare a financial emergency unit by unit was adopted. As a result, the university did begin preparation for the immediate layoff of faculty and academic staff. Shortly thereafter, all layoff notices were rescinded, and because no financial emergency was declared, the layoff process was later interpreted by staff as an administration scare tactic. But because librarians had their tenure limited to the library system, whereas faculty had tenure that was universitywide, this provision was a special threat, even though no librarians were laid off at the time.

The compensation package reflected the new administration attitude: from 1984 forward, merit pay replaced the across-the-board portion as the major compensation element. Indeed, the 1984 salary settlement called for only a 2 percent across-the-board increase. As never before, librarians were judged for merit consideration by criteria which they had not been able to resolve among themselves: publication, professional recognition, and the necessary time and means to meet these requirements.

Additionally, the university agreed to an early retirement plan which would allow senior staff of thirty years service to get five years of bonus retirement pay that would not affect the TIAA-CREF retirement plan. In theory, high-paid senior staff would be replaced by young staff, and salary savings would accrue. In reality, the economics of the times usually required that new staff be offered higher salaries than the monies left in 
salary savings from the vacant position minus the early retirement pay. Thus, this provision resulted in the hiring of an increasing number of part-time staff in the libraries. The major effect of this plan was a decrease in the full-time staff and fewer librarians eligible for the bargaining unit. In 1972, there were two parttime librarian positions; by 1992 , from nine to eleven part-time librarian positions were regularly filled.

This contract also adversely affected librarians' rights to sabbaticals comparable to faculty's. A new short-term sabbatical procedure was instituted in which librarians were eligible for 80 percent reimbursement whereas faculty were allowed 100 percent. The university's justification was that faculty had unique research needs. AAUP negotiators, all teaching faculty, accepted this reasoning, thus breaking a tradition predating unionization wherein librarians and faculty had the same sabbatical privileges. No longer was the idea of the librarian as scholar, comparable to faculty, tacitly accepted.

The most disturbing aspect of the 1984-86 contract, however, was the university's insistence on a new classification of academic staff, called academic associate. It was a term-contract job category for those employees whose assignments did not warrant the publication/research path necessary for tenure consideration. By agreement, this classification was to be limited to 30 percent of the bargaining unit. In practice, tenure-track positions were no longer offered to librarians being newly hired.

Moreover, the 1984-86 contract criteria for promotion made it all but impossible for librarians to be promoted to the Librarian IV rank. The requirement of substantial publication as well as considerable national or regional recognition, which are teaching faculty criteria for promotion to the highest rank with no consideration of academic librarian skills, has meant that, as of late 1992, no librarian has been promoted to this rank since 1986.

As a result of the 1984-86 contract, the morale among WSU librarians immediately began to wane. After administration denial of tenure in 1985 to one respected librarian who had the requisite publication and professional recognition, a number of librarians opted to renounce the tenure track option in favor of the academic associate rank in which publication and other traditional scholarly pursuits were not required. The unsettled issue of release time and the uncertain standards for publication and professional recognition had proven insurmountable.

By 1987 , only five recently hired librarians remained on the tenure track. In early 1991, these five librarians also renounced this option as not worth the effort, given the uncertain criteria and lack of administrator support. Librarians eligible to retire under the early retirement plan did so, rather than work under conditions in which they perceived that traditional scholarship and service were neither encouraged nor recognized. In addition, professional assignments previously held by librarians were increasingly given to nonprofessionals. Included in such reassignment to nonlibrarians were personnel administration, collection development, and grants and development. Also, the increasing numbers of librarians within the library system who were hired on term contracts outside the bargaining unit, such as systems analysts, assistant directors, and other administrators, and whose collegial allegiance was to library administration rather than to librarians, meant that fewer "line" librarians were left to do the day-today professional work of librarianship, stressing work schedules, job responsibilities, and goodwill, and significantly reducing even further the number of librarians eligible for bargaining unit representation (see table 2). In effect, many aspects of the professional status

TABLE 2

\begin{tabular}{ccc}
\multicolumn{3}{c}{ RATIO OF ADMINISTRATORS TO } \\
\multicolumn{2}{l}{ LIBRARIANS FOR SELECTED YEARS } \\
\hline Year & $\begin{array}{c}\text { Administrators } \\
\text { (Unrepresented) }\end{array}$ & $\begin{array}{c}\text { Librarians } \\
\text { (Represented) }\end{array}$ \\
\hline 1972 & 3 & 56 \\
1985 & 4 & 46 \\
1992 & 14 & 26 \\
\hline
\end{tabular}


of WSU's librarians had been circumvented.

\section{THE THREE CONTRACTS FROM 1986 THROUGH 1992: MARKING TIME}

These three contracts were not settled until strikes were called by the AAUP local. Clerical union contracts were in tandem with the AAUP contracts, and these unions called strikes during the same periods. The concerted force helped to end the AAUP strikes quickly. Although each of these stoppages was short and usually resulted in no loss of pay for employees, the morale of the entire university was adversely affected, especially in the libraries. It was not only the us-versus-them attitude of the staff and administration but also that of the strikers-versus-nonstrikers attitude as well. Even more divisive was that, of the two UAW locals representing library support staff, one union settled, and its members were told by its leaders to cross the picket lines of co-workers whose local had not yet settled.

And by the 1984 negotiations, librarians had become so mired in the issues of criteria for faculty status that they failed to adequately represent their bargaining position to the AAUP negotiating team.

The salary component of each of these contracts reflected the depressed Michigan economy and the accompanying monies, which were somewhat lower than those of earlier contracts. But the salary component also demonstrated the continued hard-line attitude of the university and library administrators. The merit component was larger than the across-the-board portion, which was generally under 3 percent. Most striking was that the President/Dean's Selective Salary pool, which was at 2 percent, was more than double that of the Unit Selective Salary pool. With more than half of the salary increases earmarked for merit, the effect is that more than 50 percent of the librarians have received a salary increase of 3 percent or less since 1986 . Merit increases are particularly low for librarians because, unlike with faculty members, the merit process for librarians follows administrative guidelines. The result has been great salary disparities among librarians, where years of service or rank have not been considered in salary adjustment.

Also of increasing concern by 1986 was the fact that the same senior librarians, because of contract guidelines, were required year after year to serve on the Salary Review Committee. These same senior librarians were also on the Tenure and Promotion Committee because, when promotions to Librarian IV all but disappeared in 1986, only Librarian IVs could vote on promotion to the IV rank, according to the contract. Therefore, the same judgments followed candidates year after year, allowing little hope for promotion or merit increases for those denied earlier. As of the end of 1992, the situation had still not been corrected.

A further frustration occurred when the Librarians Assembly was replaced by the library administration with a committee called the Libraries Forum. The Librarians Assembly was a collegial body chaired by an elected librarian that for years had provided advisory leadership in bargaining and implementing contracts. The Libraries Forum was made up of nonlibrarians, among them the library science department faculty who, along with librarians, now reported to the dean of libraries. The forum, chaired by the dean or his designee, remained responsible for the peer committees required by contract. But out of necessity, the entire area of librarians' union representation was no longer a suitable topic for forum discussion. A formal substitute for the Librarians Assembly function as a collegial meeting place to air librarian contract concerns had not, as of the end of 1992, been forthcoming.

By 1986, librarians were so concerned with promotion and tenure criteria that the WSU-AAUP, in the negotiations process, signed a letter of agreement that requested administrative review of such 
criteria. Specifically requested was the identification of an appropriate universitywide committee to be part of the second-level or presidential review process. At issue was whether the body should be a separate committee of librarians, archivists, and some faculty, or should be the same committee that reviewed faculty.

Meanwhile, unable to resolve criteria for either promotion or tenure, the $\mathrm{Li}$ braries Forum decided to survey other research libraries. Two WSU librarians, Barbara Heath and James Ruffner, sent questionnaires to most of the 110 research libraries of the Association of College and Research Libraries (ACRL). ${ }^{4}$ Of the seventy-two libraries that responded, 44 percent offered tenure to librarians. Of these 44 percent, 80 percent reported that research and publication were factors in their tenure review process but that a strong record of professional services could be substituted.

In their report, Heath and Ruffner proposed that the Libraries Forum adopt a dual track for tenure review: one track for librarians using publication and research as criteria and the other for librarians choosing professional service. As a result, the forum voted that the Tenure and Promotions Committee base its evaluation on: "(a) professional competence in the performance of academic library assignments; (b) scholarly or significant assignments; and (c) service." In compliance with the contract, these new guidelines were forwarded to the dean of libraries, who then sent them to the provost along with his recommendations. None of the dean's recommendations were revealed to the librarians.

In a subsequent tenure denial grievance filed by a librarian, the university's position was that the second point, "scholarly or significant assignments," actually meant "scholarly and/or significant professional assignments." That was the teaching faculty criterion for tenure. The librarian lost the grievance. As a tool, therefore, collective bargaining was essentially unable to help librarians replace teaching faculty criteria with the language that would better reflect academic librarian practices.
In 1987, the provost determined that librarians should be judged for tenure and promotion by a faculty-dominated committee. Ten years earlier, librarians would have been elated with such a decision, but the nontenured librarians of 1987 viewed this offer of faculty status with dismay. By then, stresses of the job, the shrinking staff, the lack of time, the lack of support by library administrators, and the ensuing malaise had taken their toll. Many WSU librarians had reached the point where they were unsure whether they even wanted faculty status.

The 1990-92 contract had the most devastating effect ever on librarian efforts to reach parity with teaching faculty in tenure and salary. In the 1990 negotiations, the WSU-AAUP leadership agreed with the university administration to introduce a new nontenure track employment system for all academic staff. Called the Employment Security System (ESS), it was similar to the 1968 staffing plan. Unlike the 1968 version, however, the latest revision made no provisions for job security. Instead, a twelve-month notification period was all that was required for nonrenewal of contracts, and no written cause for nonrenewal had to be given for the first four years of employment. As a result, two librarians were dismissed in 1991.

Most disturbing is that the ESS requires annual renewal, which is a destabilizing provision that gives new librarians little time to develop professional skills, pursue independent research, and study for professional development not directly related to job assignments given by supervisors. Previous contracts were for two or three years. If library administrators do not need to show cause for contract nonrenewal, then newer librarians are unable to participate in criteria, particularly professional responsibilities and self-determination, and academic freedom, which the ACRL cites as imperative if academic librarians are to be considered comparable to faculty. ${ }^{6}$

Tenure is still a possibility for the "star" librarian at WSU. But, in reality, it has become unachievable for rank-and- 
TABLE 3

\begin{tabular}{ccc}
\multicolumn{2}{l}{$\begin{array}{c}\text { LIBRARIAN TURNOVER RATES FOR } \\
\text { SELECTED YEARS }\end{array}$} \\
\hline $\begin{array}{c}\text { Total } \\
\text { Year }\end{array}$ & $\begin{array}{c}\text { Number of Librarians } \\
\text { of Librarians* }\end{array}$ & $\begin{array}{c}\text { with Less Than Five } \\
\text { Years' }\end{array}$ \\
\hline $1972^{\dagger}$ & 61 & 63 \\
1976 & 59 & 55 \\
1980 & 63 & 41 \\
1984 & 40 & 36 \\
1988 & 31 & 41 \\
1992 & 26 & 42 \\
\hline
\end{tabular}

Source: Figures compiled from WSU-AAUP data. Cited with the permission of the WSUAAUP.

* Some positions were filled by more than one librarian in the course of a given year.

† New librarians were hired to staff new law, medical, and science libraries

file librarians, who generally are recent graduates of library school. No mentoring, no time, and no job security mean no nurturing of younger librarians as professionals. This ensures a considerable turnover rate of new staff (see table 3 ).

Denial of tenure and promotion have prompted the most complaints and formal grievances by WSU librarians in the past six years. In only one instance has a second-level review committee reversed the departmental decision on such issues. And in late 1991, the library administration tried to terminate the employment of a tenured librarian, the first such attempt that had ever been made on a librarian at the university.

By 1990, the discrepancy between salaries of faculty and librarians was similar to that of the 1972 level: base nine-month faculty salary equated to base eleven-month librarian salary. This difference is because of contract emphasis on merit awards since 1984; the continuing high turnover rates of librarians, which means that the overall salary pool is always lower for librarians as a group; and the lack of promotion to the higher ranks, which also contributes to the overall salary pool for librarians being lower than that for faculty.

As for promotion monies, the 1990 contract changed the formula for recog- nizing faculty and academic staff promotions. Previously, all promotions for either faculty or academic staff were recognized by a dollar amount reflecting the new rank. The new contract retained the dollar increases for faculty and called for a straight 5 percent increase, without regard to rank, for academic staff, including librarians.

In summary, as of late 1992, initial librarian gains achieved through collective bargaining remained largely in two areas: professional development and participatory management. Librarians were still eligible for travel funds, tuition reimbursement, sabbaticals, and professional leaves. They were full members of the Academic Senate (formerly University Council) and its related committees, and participated in library governance through the Salary Review, Tenure and Promotion, Budget Advisory, Travel, and Dean's Review committees. Otherwise, since 1984, librarians have seen tenure options and salaries eroded, and promotions thwarted. Also, they were no longer eligible for the same sabbatical remunerations as faculty, and have suffered a steady loss of numbers eligible for bargaining unit representation.

\section{The Prospects}

WSU librarians have arrived at a crossroads. It remains to be seen whether they can develop a homogeneous position on academic status and then, as a small group in a 1,300-member bargaining unit, assert themselves effectively in the bargaining process to achieve this goal. Bargaining unit representation at WSU is currently at twenty-six librarians (ten of whom have tenure), thirty less than the fifty-six who were part of the 1,800-member bargaining unit in 1972. Contracts generally have been ineffective in addressing the unique academic staff situation. For example, the WSU-AAUP acceptance of a nontenured classification, academic associate, and the ESS as a substitute for tenure, have both had a negative impact on librarians' status as professionals. But to date librarians have not taken action to remove themselves from the collective bargaining process or 
the AAUP. Rather, they still see bargaining as their one means of achieving and maintaining professional status and protecting their rights, and that it is up to themselves, as a group, to make the bargaining process work for them at this crucial time.

Meeting informally, because the Libraries Forum is no longer a suitable arena for collegial discussion of contract concerns, WSU libraries have developed a position statement for WSU-AAUP negotiations that includes two immediate goals: corrective changes in the ESS that would require written reasons for contract nonrenewals, thus ensuring due process; and corrective changes in the composition of the Tenure and Promotion Committee that would eliminate the requirement that only Librarian IVs vote on promotions to the Librarian IV rank, thereby better reflecting the current composition of librarians within the bargaining unit. Achievement of these two goals would allow librarians to address two current major concerns over academic status: job security and promotions, both of which, in turn, impact salaries for librarians as a group.

The ultimate correction of tenure and promotions problems is still a viable goal for future negotiations. Successful adoption and implementation of the twotrack career ladder would resolve much of the unease felt by WSU librarians over such issues. Because of the weakened Michigan economy, however, reintroduction of this plan in contract negotiations may not be feasible at this time. Adoption of the plan as a future goal of negotiation is a strong possibility, but one whose ultimate success will be dependent upon librarians' willingness to spend the time, energy, and concerted effort necessary to prevail in the bargaining process and in implementation.

\section{Perspective}

In the twenty years of collective bargaining at WSU, librarians missed three key opportunities to resolve definitively the issue of faculty status to their own benefit. In 1971, the Michigan Employ- ment Relations Commission ruled that WSU's faculty and librarians should be in the same bargaining unit because of their "similar interests." But librarians were unable to agree among themselves on the workload and release time necessary to fulfill publication and professional recognition requirements as set by faculty standards. In 1976, WSUAAUP negotiators offered to pursue again the issue of full faculty status for librarians, but, as in 1971, librarians could not develop a common position among themselves on publication, scholarly research, and release time. By 1976 , technical services librarians maintained strongly that the nature of their responsibilities precluded the opportunities for research and publication offered to public services librarians. In 1980 , the possibility of full faculty status for librarians, as separate from academic staff, was reintroduced by both university and AAUP negotiators. But, among librarians, the issues of release time and criteria for promotion and tenure were still unresolved-and have remained so.

In effect, librarians over the years have declined full faculty status while still aspiring to it. Currently, the criteria for evaluating librarians for promotion and merit are based mainly on faculty standards. Whether they want it or not, WSU librarians are considered as faculty for such considerations, but they do not realize the benefits of such status in salaries, sabbaticals, or (for newer librarians) job security. Until the university's librarians come to terms with the requirements of faculty status, through negotiation among themselves and then with union and university negotiators, they are likely to remain in this paradoxical position. Perhaps the most salient lesson of the WSU experience, therefore, is that for collective bargaining to work successfully for academic librarians on the faculty status issue, librarians first must agree among themselves on each aspect of such status and then present a concerted front in the bargaining and contract implementation process. 


\section{REFERENCES AND NOTES}

1. For a complete description of the initial unionization of WSU's librarians, see Lothar Spang, "Collective Bargaining and University Librarians: Wayne State University," College \& Research Libraries, 36 (Mar. 1975): 106-14.

2. Wayne State University Libraries, Tenure and Promotion Committee, Report of the 1977/78 Tenure and Promotion Committee to the Libraries, Detroit, Michigan.

3. Francine Wehmer, president, Wayne State University Chapter, American Association of University Professors, letter to the Wayne State University Librarians Assembly, Feb. $6,1980$.

4. Barbara Heath and James Ruffner, Preliminary Report to the Libraries Forum from the Tenure and Promotion Committee, Subcommittee to Investigate Librarian Research Standards, Feb. 12, 1987.

5. Wayne State University Libraries, Libraries Forum, Guidelines for Appointment, Promotion, and Tenure of University Librarians, Mar. 1987.

6. Association of College \& Research Libraries, "ACRL Guidelines for Academic Status for College and University Libraries," College \& Research Libraries News, 51 (Mar. 1990): 245-46.

\section{Entrust your endangered material to MAPS}

- Highest quality preservation microfilming-150+ line resolution images

- MAPS patented exposing system-Exceptionally narrow density ranges for better duplication

- Polysulfide treatment-Protects your film against oxidation damage (measles)

- Herrmann \& Kraemer cameras-Highest quality, computer-controlled cameras

- Fast, reliable turnaround for your projects

- Facilitate scanning of film-High resolution, consistent density, blipping and frame numbering

Preserve your endangered material and prepare for our digital future. With an environmentally controlled laboratory and specially trained staff, MAPS is devoted exclusively to archival-quality preservation microfilming, storage of print masters, and film duplication services. Call MAPS for more information and prompt estimates.

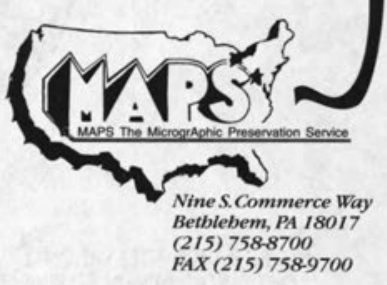


Companies venturing into former Eastern Bloc countries are met with virtually limitless

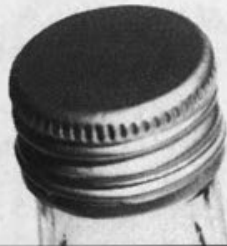
opportunity-and virtually nonexistent hard currency. So, those eager to forge new markets are willing to accept some unconventional forms of exchange. Pepsi Cola, for example, gets paid in the most liquid of assets, vodka.

\section{Companies doING BUSINESS IN FORMER EASTERN BLOC COUNTRIES HAVE DISCOVERED A CURRENCY FAR STRONGER THAN THE RUBLE.}

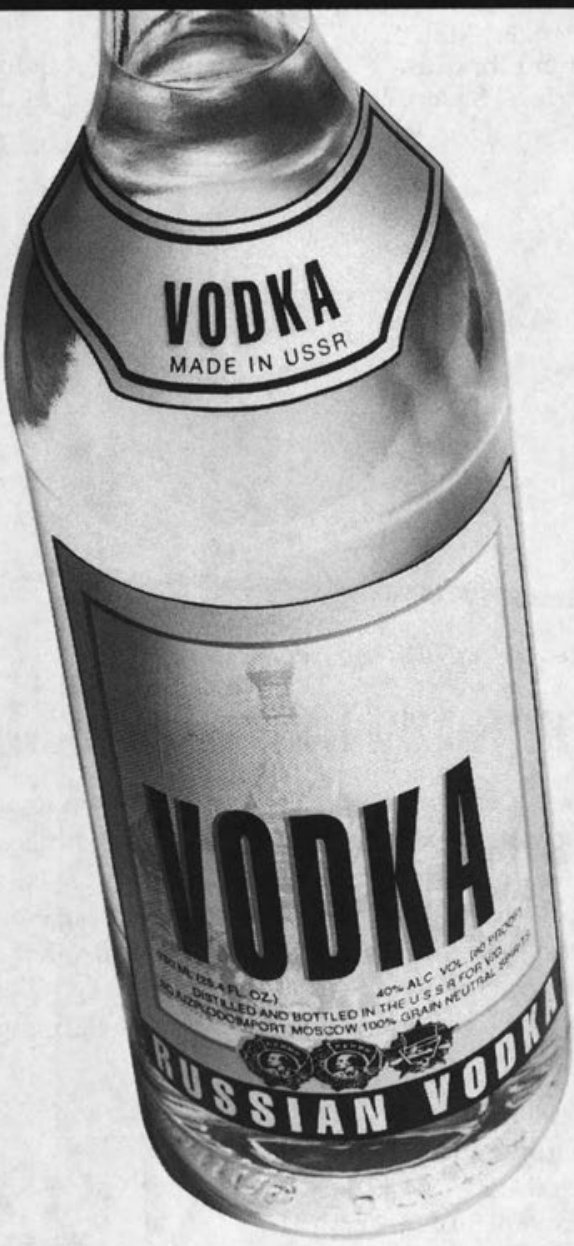

The precarious state of Eastern Europe's economy and the innovative ways Western businesses are working within it are topics of tremendous interest. And they're just two of the thousands of important subjects covered by PAIS International.

\section{Easy access to hard-to-find data}

From shifting global politics and international statistics, to domestic legislation and import export regulations, PAIS offers you information you won't find anywhere else. PAIS online and CD-ROM indexes provide access to over 350,000 journal articles, government documents, statistical directories, monographs, conference reports and more. And to provide an unrivaled international perspective, PAIS references literature published around the world in English, French, German, Italian, Spanish and Portuguese.

So the next time you're thirsty for straight information, go for the strong stuff. PAIS.

Public Affairs Information Service, Inc.

521 West 43rd Street, New York, NY 10036-4396

800-288-PAIS, 212-736-6629 (in NYC) Fox: 212-643-2848

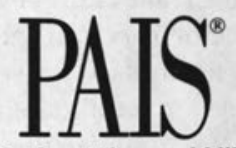

No one looks at the world like PAIS

In Print: PAIS INTERNATIONAL IN PRINT ${ }^{\bullet}$ - PAIS SUBIECT HEADINGS Online Through: DATA.STAR • DIALOG • OCLC • RLG On CD-ROM: PAIS ON CD-ROM - PAIS INTERNATIONAL ON SILVERPLATTER On Magnetic Tape: CONTACT PAIS FOR INFORMATION 